\title{
Neurotoxic effects of mercury exposure for dental workers - A literature review
}

\author{
Claudia Florina Andreescu*1 \\ ${ }^{1}$ Department of Prosthetics, Faculty of Dental Medicine, University Titu Maiorescu, Bucharest, Romania
}

\begin{abstract}
This aim of this review is to estimate neurotoxic effects of mercury exposure among dental personnel. The electronic search in the database PubMed revealed 15 papers that investigated relationship between mercury occupational hazard and neurologic and psychological effects in dental professionals. Based on the studies reviewed could be concluded that chronic exposure to mercury might have central nervous system effects.
\end{abstract}

\section{Introduction}

Dental amalgams fillings are used for more than 150 years due to low cost, ease of application, strength, and durability [1]. Dental amalgam is made by reaction (amalgamation) between liquid mercury and metal alloy powders (silver, tin, copper, zinc). Mercury, which makes up about $50 \%$ of the compound, is used to bind the metals together and to provide a strong, hard, durable filling.

Concern for appearance, environmental pollution, health, and the availability of improved, reliable, composite materials have diminished the use of amalgam restorations [2]. In particular, concerns about the toxicity of mercury have made its use increasingly controversial [3]. Mercury's toxic effects in humans include: damage to the brain, kidneys, immune and reproductive system [4]. Mercury can be absorbed through the skin and mucous membranes, but $80 \%$ of mercury vapour absorption occurs through the lungs [5] and then entering into bloodstream. Following distribution by blood circulation, mercury enters and remains in certain tissues and primary target organs of concern are the central nervous system and kidneys [6]. Therefore, the earliest signs of subclinical intoxication of mercury can appear on the target organs $[7,8]$.

People who are handling mercury are at risk and dental personnel are ones of professionals who are working with mercury. Numerous studies reveal high concentration of mercury in blood, hair, nails and urine of dental staff [9-12]. The purpose of this article is to review neurotoxic effects of mercury exposure for dental personnel.

\section{Material and method}

The present review includes studies about dental workers exposed to mercury and evaluation of personnel's heath (Table 1).

\section{Results}

The electronic search in the database PubMed provided a total number of 288 titles that were considered potentially relevant. In the second phase of study selection, only 33 articles were sampled and checked for correlation between chronic exposure to mercury and effects on central nervous system (CNS). Subsequently 15 papers were reviewed for possible effects of occupational exposure of mercury on CNS among dental staff (Table 2).

\section{Discussion}

The revised paper investigated different possible consequences of chronic exposure to mercury; the first 33 articles investigated correlation between chronic exposure of low dose of mercury and health effects. 15 papers examined effects on nervous central system, and others try to establish possible correlation between chronic mercury exposure and allergic contact dermatitis, immunological effects, pituitary function, skeletal muscle abnormalities, pregnancy outcome, blood pressure or melanoma.

The classic symptoms associated with exposure to elemental mercury vapour $(\mathrm{Hg} 0)$ and methylmercury $(\mathrm{MeHg})$ involve CNS [13]. Neurotoxicity of mercury associated with occupational exposure where known from Middle Eve among mirror makers [14] and hat makers

Table 1. Search strategy.

\begin{tabular}{|l|l|}
\hline Study group & Dental workers \\
\hline Condition & Exposure to mercury \\
\hline Outcome & $\begin{array}{l}\text { Health effects related to chronic mercury exposure. Neurotoxicity } \\
\text { correlated to chronic mercury exposure }\end{array}$ \\
\hline Search combination & $\begin{array}{l}\text { "mercury dental workers": } 81 \text { hits, "mercury dental personnel": } \\
121 \text { hits, "mercury dental staff": } 86 \text { hits }\end{array}$ \\
\hline Database search & Electronic PubMed \\
\hline $\begin{array}{l}\text { Selection criteria } \\
\text { phase one }\end{array}$ & $\begin{array}{l}\text {-Inclusion criteria: Studies about consequences of mercury } \\
\text { exposure for dental workers, published in English } \\
\text {-Exclusion criteria: Studies in languages other than English, others } \\
\text { professionals exposed to mercury than dental workers }\end{array}$ \\
\hline $\begin{array}{l}\text { Selection criteria } \\
\text { phase two }\end{array}$ & $\begin{array}{l}\text {-Inclusion criteria: Studies about consequences of mercury } \\
\text { exposure on central nervous system } \\
\text {-Exclusion criteria: Studies about other consequences of mercury } \\
\text { exposure than on central nervous system }\end{array}$ \\
\hline
\end{tabular}

Correspondence to: Claudia Florina Andreescu, DDS, PhD, Associate Professor, Faculty of Dental Medicine, University Titu Maiorescu, Bucharest, 67A Gheorghe Petrascu Street, sector 3, Bucharest, code 031593, Romania, Tel/Fax: +4021.325.14.16, E-mail: claudia_andreescu@yahoo.com

Key words: mercury exposure, neurotoxicity, dental personnel

Received: March 10, 2017; Accepted: March 23, 2017; Published: March 27, 2017 
Table 2. Summary of studies about neurotoxic effects of mercury exposure for dental workers.

\begin{tabular}{|c|c|c|c|c|c|}
\hline Reference & Objective & Batch & Type of investigation & Findings & Conclusions \\
\hline $\begin{array}{l}\text { Uzzell et al. } \\
1986 \text { [17] }\end{array}$ & $\begin{array}{c}\text { To measure the effects of } \\
\text { chronic low-level exposure } \\
\text { to inorganic mercury, } \\
\text { the neuropsychological } \\
\text { performances. }\end{array}$ & $\begin{array}{c}13 \text { female } \\
\text { dental } \\
\text { auxiliary } \\
\text { workers }\end{array}$ & $\begin{array}{l}\text { Battery test: Recurrent Figures, } \\
\text { SCL-90-R, WAIS, Rey's } \\
\text { AVL, PASAT, BGT, Grooved } \\
\text { Pegboard, and Finger Tapping } \\
\text { tests. }\end{array}$ & $\begin{array}{l}\text { Workers with elevated mercury levels scored } \\
\text { significantly less well on the Recurrent Figures, } \\
\text { and SCL-90-R. }\end{array}$ & $\begin{array}{l}\text { Chronic subtoxic levels of inorganic } \\
\text { mercury appear to produce mild changes in } \\
\text { short-term nonverbal recall and heightened } \\
\text { distress generally, and particularly in } \\
\text { categories of obsessive compulsion, anxiety } \\
\text { and psychoticism, without alterations in } \\
\text { general intellectual functioning, attention, } \\
\text { verbal recall, and motor skills. }\end{array}$ \\
\hline $\begin{array}{l}\text { Nilsson et al. } \\
\quad 1990[18]\end{array}$ & $\begin{array}{l}\text { Evaluation of four } \\
\text { symptoms known to be } \\
\text { connected with mercury } \\
\text { exposure. }\end{array}$ & $\begin{array}{c}505 \\
\text { dental } \\
\text { workers }\end{array}$ & $\begin{array}{l}\text { Questionnaire focused on four } \\
\text { symptoms: loss of appetite, } \\
\text { tremor, insomnia and anxiety }\end{array}$ & $\begin{array}{l}\text { The prevalence of any of the four symptoms } \\
\text { investigated in the groups of exposed personnel } \\
\text { and controls as low, less than or equal to } 11 \% \text {. }\end{array}$ & $\begin{array}{l}\text { No increase in the prevalence of symptoms } \\
\text { could be detected in relation to mercury } \\
\text { concentrations in urine. }\end{array}$ \\
\hline $\begin{array}{l}\text { Glina et al. } \\
1997[19]\end{array}$ & $\begin{array}{c}\text { Evaluation of health status } \\
\text { of dental staff exposed to } \\
\text { mercury. }\end{array}$ & $\begin{array}{l}8 \text { dental } \\
\text { workers }\end{array}$ & $\begin{array}{l}\text { Evaluation of health status: } \\
\text { anamnesis, clinical and battery } \\
\text { test: WMS, Leon Walther } \\
\text { Mechanics Aptitude Test, } \\
\text { Toulouse Picron Concentrated } \\
\text { Attention Test, WAIS. }\end{array}$ & $\begin{array}{l}\text { Symptoms related to the neurological condition } \\
\text { (headache, cramps, paraesthesia, tremor, } \\
\text { dizziness, muscle weakness, forgetfulness } \\
\text { and difficulty concentrating) and the psychic } \\
\text { condition (irritability, nervousness, depression } \\
\text { and insomnia) were mentioned. }\end{array}$ & $\begin{array}{l}\text { Prevalence of symptoms from lesions to } \\
\text { the central nervous system; central nervous } \\
\text { system signs; and mild-to-moderate chronic } \\
\text { poisoning was found in } 62.5 \% \text { of workers. }\end{array}$ \\
\hline $\begin{array}{l}\text { Bittner et al. } \\
1998[20]\end{array}$ & $\begin{array}{l}\text { Evaluation the sensitivities } \\
\text { of five psychomotor tasks. }\end{array}$ & $\begin{array}{c}230 \\
\text { dental } \\
\text { workers }\end{array}$ & $\begin{array}{l}\text { Battery test: IHST; Finger } \\
\text { Tapping: The One-Hole Test: } \\
\text { NES SRT; and Hand Tremor. }\end{array}$ & $\begin{array}{l}\text { Significant associations were found for the IHST } \\
\text { factor, followed by finger tapping, which was } \\
\text { relatively meager and insignificant. }\end{array}$ & $\begin{array}{l}\text { Results indicated remarkable differences } \\
\text { in the effects of relative level of } \mathrm{Hg} 0 \text { on } \\
\text { psychomotor performance. }\end{array}$ \\
\hline $\begin{array}{l}\text { Echeverria } e t \\
\text { al. } 1998[21]\end{array}$ & $\begin{array}{l}\text { Evaluation of potential } \\
\text { CNS toxicity associated } \\
\text { with handling Hg- } \\
\text { containing amalgam } \\
\text { materials. }\end{array}$ & $\begin{array}{c}37 \text { dental } \\
\text { workers }\end{array}$ & Battery test NES. & $\begin{array}{l}\text { Adverse behavioural effects (alterations in } \\
\text { mood, reduction in speed and accuracy in motor } \\
\text { function, and subtle losses in memory and } \\
\text { visuospatial cognitive skills) associated with low } \\
\text { Hg0 exposures. }\end{array}$ & $\begin{array}{l}\text { Subtle preclinical effects on symptoms, } \\
\text { mood, motor function, and cognition were } \\
\text { found associated with Hg body burden. }\end{array}$ \\
\hline $\begin{array}{l}\text { Urban et al. } \\
1999[22]\end{array}$ & $\begin{array}{l}\text { Neurological, visual } \\
\text { evoked potentials (VEP) } \\
\text { and electroneurography } \\
\text { examinations on three } \\
\text { groups of workers. }\end{array}$ & $\begin{array}{c}36 \text { dental } \\
\text { workers }\end{array}$ & Neurological examination. & $\begin{array}{l}\text { The exposure of dental professionals was mild. } \\
\text { Symptoms and signs of micromercurialism were } \\
\text { observed only in the group with the highest } \\
\text { exposure to Hg. }\end{array}$ & $\begin{array}{l}\text { The combination of a decrease in sural } \\
\text { nerve conduction velocity and an abnormality } \\
\text { of VEP seems to be a characteristic pattern } \\
\text { of electrophysiological changes in persons } \\
\text { exposed to mercury vapours. }\end{array}$ \\
\hline $\begin{array}{l}\text { Ritchie et al. } \\
2002[23]\end{array}$ & $\begin{array}{l}\text { Finding the effect of } \\
\text { chronic exposure to } \\
\text { mercury on health and } \\
\text { cognitive functioning. }\end{array}$ & $\begin{array}{c}180 \\
\text { dentists }\end{array}$ & Questionnaire. & $\begin{array}{l}\text { Dentists were significantly more likely than } \\
\text { control subjects to have had disorders of the } \\
\text { kidney and memory disturbance. These symptoms } \\
\text { were not significantly associated with urinary } \\
\text { mercury concentration. }\end{array}$ & $\begin{array}{c}\text { Several differences in health and cognitive } \\
\text { functioning between dentists and controls } \\
\text { were found. These differences could not } \\
\text { be directly attributed to their exposure to } \\
\text { mercury. }\end{array}$ \\
\hline $\begin{array}{l}\text { Aydin } e t \text { al. } \\
2003[24]\end{array}$ & $\begin{array}{l}\text { To evaluate possible } \\
\text { adverse effects on the CNS } \\
\text { in dental personnel. }\end{array}$ & $\begin{array}{l}43 \text { dental } \\
\text { workers }\end{array}$ & $\begin{array}{l}\text { Battery test and questionnaire: } \\
\text { WMS-R, VTMP, SCL-90-R, } \\
\text { BDI. }\end{array}$ & $\begin{array}{l}\text { Urinary concentration of } \mathrm{Hg} \text { had an inverse } \\
\text { relationship with logical memory and total } \\
\text { retention score, and a positive relationship with } \\
\text { increased scores of anxiety and psychoticism. }\end{array}$ & $\begin{array}{l}\text { These results may represent long-term } \\
\text { consequences of low Hg exposure. }\end{array}$ \\
\hline $\begin{array}{l}\text { Moen } \text { et al. } \\
2008[25]\end{array}$ & $\begin{array}{l}\text { To compare the occurrence } \\
\text { of neurological symptoms } \\
\text { among dental assistants. }\end{array}$ & $\begin{array}{r}73 \text { dental } \\
\text { assistants }\end{array}$ & Questionnaire. & $\begin{array}{l}\text { The dental assistants reported significant } \\
\text { higher occurrence of neurological symptoms; } \\
\text { psychosomatic symptoms, problems with } \\
\text { memory, concentration, fatigue and sleep } \\
\text { disturbance, but not for mood. }\end{array}$ & $\begin{array}{c}\text { There is a possibility that the higher } \\
\text { occurrence of neurological symptoms } \\
\text { among the dental assistants may be related } \\
\text { to their previous work exposure to mercury } \\
\text { amalgam fillings. }\end{array}$ \\
\hline $\begin{array}{c}\text { Hilt et al. } 2009 \\
{[26]}\end{array}$ & $\begin{array}{l}\text { Correlation between } \\
\text { mercury exposure and } \\
\text { cognitive effects. }\end{array}$ & $\begin{array}{c}608 \\
\text { dental } \\
\text { assistants }\end{array}$ & Questionnaire. & $\begin{array}{l}\text { Dental assistants reported more cognitive } \\
\text { symptoms than the controls }\end{array}$ & $\begin{array}{l}\text { The occurrence of cognitive malfunction } \\
\text { may be moderately increased in dental } \\
\text { assistants. }\end{array}$ \\
\hline $\begin{array}{l}\text { Thygesen et al. } \\
2011[27]\end{array}$ & $\begin{array}{l}\text { To compare hospital } \\
\text { admissions due to } \\
\text { neurological and renal } \\
\text { diseases between dental } \\
\text { staff and control. }\end{array}$ & \begin{tabular}{|c|}
5371 \\
dentists \\
and \\
33858 \\
dental \\
assistants
\end{tabular} & Records of hospital admission. & $\begin{array}{l}\text { For neurological diseases, no association was } \\
\text { observed for dental assistants, while for dentists } \\
\text { an increasing risk for periods with less mercury } \\
\text { exposure was observed. Among dental assistants, } \\
\text { a negative association between employment length } \\
\text { and risk of neurological disease was observed. }\end{array}$ & $\begin{array}{l}\text { Occupational exposure to mercury does not } \\
\text { increase the risk of hospital admissions for } \\
\text { neurological, Parkinson's or renal diseases. }\end{array}$ \\
\hline $\begin{array}{l}\text { Hilt et al. } 2011 \\
{[28]}\end{array}$ & $\begin{array}{l}\text { Prevalence of symptoms } \\
\text { consistent with } \\
\text { neurological and/or } \\
\text { cognitive malfunction in } \\
\text { dentists. }\end{array}$ & $\begin{array}{c}406 \\
\text { dentists }\end{array}$ & Questionnaire. & $\begin{array}{l}\text { The dentists reported no more cognitive } \\
\text { symptoms than the controls. }\end{array}$ & $\begin{array}{l}\text { Norwegian dentists do not report more } \\
\text { cognitive and neurological symptoms than } \\
\text { controls from the general population. }\end{array}$ \\
\hline $\begin{array}{l}\text { Sletvold et al. } \\
2012[29]\end{array}$ & $\begin{array}{l}\text { To find late developed } \\
\text { disturbances in cognitive } \\
\text { function of dental } \\
\text { personnel with previous } \\
\text { exposure to metallic } \\
\text { mercury. }\end{array}$ & $\begin{array}{c}91 \text { female } \\
\text { dental } \\
\text { workers }\end{array}$ & $\begin{array}{l}\text { Battery test and questionnaire. } \\
\text { WAIS, Finger Tapping Test, } \\
\text { short-term memory, working } \\
\text { memory, executive function, } \\
\text { mental flexibility, verbal and } \\
\text { visual long-term memory. }\end{array}$ & $\begin{array}{l}\text { The only relationship that was statistically } \\
\text { significant was between the previously measured } \\
\text { urine mercury values and visual long-term } \\
\text { memory, }\end{array}$ & $\begin{array}{c}\text { The neuropsychological findings indicative } \\
\text { of subsequent cognitive injuries are difficult } \\
\text { to find in groups of otherwise healthy } \\
\text { dental personnel with previous occupational } \\
\text { exposure to mercury. }\end{array}$ \\
\hline $\begin{array}{l}\text { Naimi-Akbar } \\
\text { et al. } 2012[30]\end{array}$ & $\begin{array}{l}\text { To investigate cognitive } \\
\text { function among offspring } \\
\text { of women working in } \\
\text { dentistry at the time of } \\
\text { their pregnancy. }\end{array}$ & 3546 & $\begin{array}{l}\text { Four test: two linguistics, one } \\
\text { for spatial recognition and one } \\
\text { for technical comprehension. }\end{array}$ & $\begin{array}{l}\text { The sons of dental workers had similar or higher } \\
\text { cognitive function test results compared to their } \\
\text { matched cohorts. }\end{array}$ & $\begin{array}{l}\text { There is no evidence of poorer cognitive } \\
\text { function among male offspring of female } \\
\text { dentists or dental nurses. }\end{array}$ \\
\hline
\end{tabular}




\begin{tabular}{|c|c|c|c|c|}
\hline & $\begin{array}{c}\text { To investigate whether } \\
\text { potential in utero exposure } \\
\text { to mercury might have } \\
\text { affected the development } \\
\text { of nervous system of the } \\
\text { sons of female dental } \\
\text { personnel. }\end{array}$ & 12110 & National registers. & $\begin{array}{c}\text { There is no elevated risk for neurological disease, } \\
\text { epilepsy or intellectual disability among the sons } \\
\text { of dental personnel }\end{array}$ \\
$\begin{array}{c}\text { The current use of dental amalgam } \\
\text { should not represent an elevated risk } \\
\text { disability among the offspring of dental } \\
\text { personnel. }\end{array}$ \\
\hline
\end{tabular}

[15]. Signs of long term exposure to mercury include: emotional instability, cognitive and memory loss, shyness, speech problems and ataxia [16], known as" mad hatter's disease".

Dentists and dental assistants are among professionals exposed to $\mathrm{HgO}$ due to dealing with amalgam fillings and $\mathrm{MeHg}$ from their own amalgam fillings. This review includes 13 studies about possible CNS effects of chronic exposure to mercury [17-29] and 2 studies about possible CNS effects on offspring of female dental professionals exposed to mercury during pregnancy $[30,31]$. All the papers compare a group of dental workers exposed to mercury proved by blood and/or urine tests with a control group.

Assessment of CNS effects was done using battery tests and/ or questionnaires or analysed of individual hospital records. Tests evaluate neuropsychological activity within the following domains: motor function, short-term memory, working memory, executive function, mental flexibility, visual and verbal long-term memory.

The papers reviewed give contradictory evidence depending on year and type of investigation.

Uzzell and Oller [17] used Recurrent Figures, SCL-90-R (Symptom Checklist 90 revised), WAIS (Wechsler Adult Intelligence Scale), Rey's AVL (Rey-Auditory Verbal Learning), PASAT (Paced Auditory Serial Addition Test), BGT (Bender-Gestalt Test), Grooved Pegboard, and Finger Tapping tests for evaluation of neuropsychological performances of 13 female dental assistants and found mild changes.

Bittner, et al. [20] performed also psychomotor five tests: Intentional Hand Steadiness Test (IHST); Finger Tapping; The OneHole Test; NES Simple Reaction Time (SRT); and Hand Tremor and determined a significant associations between the IHST and Hg0 level.

Other study from 1998 [21] associated questionnaire with Neurobehavioral Evaluation System (NES) tests on 49 dental workers and discovered subtle alterations of motor, memory and cognitive skills. The same association was done by Aydin, et al. [24] and established a positive relationship with increased scores of anxiety and psychoticism using SCL-90-R test in a group of 43 dental workers. Sletvold, et al. [29] discovered a statistically significant relationship between measured urine mercury level and visual long-term memory based on evaluation of 91 female dental workers by questionnaire and neuropsychological tests.

Questionnaire based studies [18,23,25,26,28] could assess more dental workers than previously mention studies and generally concluded that symptoms of CNS could not be related with chronic mercury exposure, but dental assistants seems to have more cognitive symptoms than dentist $[25,26,28]$ possible because dental assistants are more exposed than dentists. Glina, et al. [19] based on 8 questionnaires reported neurological and psychic effects.

Studies done before 2010 revealed associations between CNS symptoms and chronic mercury exposure, except study conducted Nilson, et al. in 1990. Studies that used different battery tests for neuropsychological examination noticed a significant correlation between CNS symptoms and chronic mercury exposure. In contrast, studies based only on questionnaire found moderate or no link between neurological symptoms and occupational exposure.

Studies from 2011 do not associate neurological symptoms with chronic mercury exposure. This is related with regulations in amalgam use, occupational health training in handling dental amalgam and improvement in working conditions, especially improvement of ventilation, because inhalation of vapour is the main route for exposure in dental workers. All these measures reduced mercury exposure. In 1991 World Dental Federation [32] recognized that "a potential health risk to oral health personnel from mercury exposure exists if working conditions are not properly organised" and "application of proper mercury hygienic requirements together with monitoring of mercury vapours in the work environment in dental clinics will significantly reduce mercury exposure".

When compared with other mercury exposed workers, dental professionals' exposure was mild, no signs of micromercurialism were revealed, but a shortening of visual evoked potentials (VEP) latency was discovered in all groups [22] and this is associated with cerebral cortex activity. This is the only study that correlate exposure to mercury vapours with a certain test, namely VEP. Unfortunately, the relationship between VEP, chronic mercury exposure and dental professionals has not been investigated further, but VEP latency was correlated with mercury exposure due to food contamination [33].

Although the neurophysiological tests revealed an association between chronic mercury exposure and CNS findings among dental professionals, there is not a specific test to show this and also no specific CNS symptom. .

More recent studies made different correlation between occupational mercury exposure and CNS effects. Thygesen, et al. [27] compare hospital admissions due to neurological and renal diseases among dental workers and a control group and could not establish a positive relationship.

Naimi, et al. [30] and Vähäsarja, et al. [31] investigated the relationship between mercury exposure during pregnancy and cognitive function, respectively risk of neurological disease among offspring of dental workers. This is in accordance with previous findings, which suggested that placenta and foetal membranes might serve as a protection for the foetus against mercury exposure [34].

Occupational exposure is different from mercury exposure due to amalgam fillings, because amalgam aged for two years did not release mercury [35]. Different studies tried to correlate mercury eliminated from dental amalgam fillings with diverse health effects. A study from 1988 [36] aimed to investigate whether fatigue, a CNS effect, is related to the number of tooth surfaces of amalgam or to other factors and concluded that other factors (psychosocial factors and the frequency of sick-leave in respiratory diseases) rather than the release of mercury from dental amalgam could explain the symptoms of fatigue. Bates, et al. [37] performed a retrospective cohort study and examined associations with medical diagnostic categories, particularly disorders of the nervous system and kidney with mercury exposure from amalgam fillings. They concluded that there is a limited evidence of an 
association between amalgam and disease.

Despite of controversy amalgam is still used worldwide for dental fillings because is durable and affordable [38] and in posterior teeth amalgam restorations have a better longevity and less number of secondary caries when compared to colour-tooth restorations [39].

\section{Conclusion}

As this review has shown, earlier studies associate chronic exposure to mercury with CNS effects and later studies could not relate neuropsychological symptoms with mercury chronic exposure in dental professionals. Studies that used different neuropsychological tests noticed a significant correlation between CNS symptoms and chronic mercury exposure, but studies based only on questionnaire found moderate or no link between neurological symptoms and occupational exposure. There is not a specific neurophysiological test characteristic to chronic mercury exposure, only VEP latency is characteristic to mercury vapours exposure.

\section{References}

1. Bharti R, Wadhwani KK, Tikku AP, Chandra A (2010) Dental amalgam: An update. $J$ Conserv Dent 13: 204-208. [Crossref]

2. Shenoy A (2008) Is it the end of the road for dental amalgam? A critical review. $J$ Conserv Dent 11: 99-107. [Crossref]

3. Mackey TK, Contreras JT, Liang BA (2014) The minamata convention on mercury: Attempting to address the global controversy of dental amalgam use and mercury waste disposal. Sci Total Environ 472: 125-129. [Crossref]

4. Zahir F, Rizwi SJ, Haq SK, Khan RH (2005) Low dose mercury toxicity and human health. Environ Toxicol Pharmacol 20: 351-360. [Crossref]

5. Reinhardt JW (1992) Side-effects: mercury contribution to body burden from dental amalgam. Adv Dent Res 6: 110-113. [Crossref]

6. Nylander M, Friberg L, Eggleston D, Björkman L (1988) Mercury accumulation in tissues from dental staff and controls in relation to exposure. Swedish dental journal 13: 235-243. [Crossref]

7. Bhan A, Sarkar NN (2005) Mercury in the environment: effect on health and reproduction. Rev Environ Health 20: 39-56. [Crossref]

8. Clarkson TW, Magos L (2006) The toxicology of mercury and its chemical compounds. Crit Rev Toxicol 36: 609-662. [Crossref]

9. Ott KH, Grimmeisen J, Alt F, Messerschmidt J, Tölg G (1991) Mercury in the hair of dentists and dental personnel. Dtsch Zahnarztl Z 46: 154-158. [Crossref]

10. Gonzalez-Ramirez D, Maiorino RM, Zuniga-Charles M, Xu Z, Hurlbut KM, JuncoMunoz P, et al. (1995) Sodium 2, 3-dimercaptopropane-1-sulfonate challenge test for mercury in humans: II. Urinary mercury, porphyrins and neurobehavioral changes of dental workers in Monterrey, Mexico. J Pharmacol Exp Ther 272: 264-274. [Crossref]

11. Tezel H, Ertas OS, Ozata F, Erakin C, Kayali A (2001) Occupational health: blood mercury levels of dental students and dentists at a dental school. British Dental Journal 191: 449-452.

12. Morton J, Mason HJ, Ritchie KA, White M (2004) Comparison of hair, nails and urine for biological monitoring of low level inorganic mercury exposure in dental workers. Biomarkers 9: 47-55. [Crossref]

13. Aschner M, Aschner JL (1990) Mercury neurotoxicity: mechanisms of blood-brain barrier transport. Neurosci Biobehav Rev 14: 169-176. [Crossref]

14. Alessio L, Campagna M, Lucchini R (2007) From lead to manganese through mercury: mythology, science, and lessons for prevention. Am J Ind Med 50: 779-787. [Crossref]

15. Bigham G, Henry B, Bessinger B (2005) Mercury-A tale of two toxins. Natural Resources \& Environment 19: 26-71.

16. Wedeen RP (1989) Were the hatters of New Jersey "mad"? Am J Ind Med 16: 225-233. [Crossref]

17. Uzzell BP, Oler J (1986) Chronic low-level mercury exposure and neuropsychological functioning. J Clin Exp Neuropsychol 8: 581-593. [Crossref]

18. Nilsson B, Gerhardsson L, Nordberg GF (1990) Urine mercury levels and associated symptoms in dental personnel. Sci Total Environ 94: 179-185. [Crossref]
19. Glina DM, Satut BT, Andrade EM (1997) Occupational exposure to metallic mercury in the dentist's office of a public primary health care clinic in the city of São Paulo. Cad Saude Publica 13: 257-267. [Crossref]

20. Bittner AC, Echeverria D, Woods JS, Aposhian HV, Naleway C, Martin MD, et al. (1998) Behavioral effects of low-level exposure to $\mathrm{Hg} 0$ among dental professionals: a cross-study evaluation of psychomotor effects. Neurotoxicol Teratol 20: 429-439. [Crossref]

21. Echeverria D, Aposhian HV, Woods JS, Heyer NJ, Aposhian MM, Bittner AC Jr, et al (1998) Neurobehavioral effects from exposure to dental amalgam $\mathrm{Hg} 0$ : new distinctions between recent exposure and $\mathrm{Hg}$ body burden. FASEB J 12: 971-980. [Crossref]

22. Urban P, Lukáš E, Nerudová J, Čábelková Z, Cikrt M (1999) Neurological and electrophysiological examinations on three groups of workers with different levels of exposure to mercury vapors. Eur J Neurol 6: 571-577. [Crossref]

23. Ritchie KA, Gilmour WH, Macdonald EB, Burke FJ, McGowan DA, Dale IM, et al (2002) Health and neuropsychological functioning of dentists exposed to mercury. Occup Environ Med 59. 287-293. [Crossref]

24. Aydin N, Karaoglanoglu S, Yigit A, Keles MS, Kirpinar I, Seven N (2003) Neuropsychological effects of low mercury exposure in dental staff in Erzurum, Turkey. Int Dent J 53: 85-91. [Crossref]

25. Moen B, Hollund B, Riise T (2008) Neurological symptoms among dental assistants: a cross-sectional study. J Occup Med Toxicol 3: 10. [Crossref]

26. Hilt B, Svendsen K, Syversen T, Aas O, Qvenild T, Sletvold H, et al. (2009) Occurrence of cognitive symptoms in dental assistants with previous occupational exposure to metallic mercury. Neurotoxicology 30: 1202-1206. [Crossref]

27. Thygesen LC, Flachs EM, Hanehøj K, Kjuus H, Juel K (2011) Hospital admissions for neurological and renal diseases among dentists and dental assistants occupationally exposed to mercury. Occup Environ Med 68: 895-901. [Crossref]

28. Hilt B, Svendsen K, Syversen T, Aas O, Qvenild T (2011) Occurrence of cognitive and neurological symptoms in Norwegian dentists. Saf Health Work 2: 176-182. [Crossref]

29. Sletvold H, Svendsen K, Aas O, Syversen T, Hilt B (2012) Neuropsychological function and past exposure to metallic mercury in female dental workers. Scand $J$ Psychol 53: 136-143. [Crossref]

30. Naimi-Akbar A, Sandborgh-Englund G, Ekbom A, Ekstrand J, Montgomery S (2012) Cognitive function among sons of women who worked in dentistry. Scand $J$ Work Environ Health 38: 546-552. [Crossref]

31. Vähäsarja N, Montgomery S, Sandborgh-Englund G, Ekbom A, Ekstrand J, Näsman $\mathrm{P}$, et al. (2016) Neurological disease or intellectual disability among sons of female Swedish dental personnel. J Perinat Med 44: 453-460. [Crossref]

32. FDI Policy Statement. WHO Consensus Statement on Dental Amalgam. Available at http://www.fdiworldental.org/media/11399/WHO-consensus-statement-on-dentalamalgam-1997.pdf.

33. Yorifuji T, Murata K, Bjerve KS, Choi AL, Weihe P, Grandjean P (2013) Visual evoked potentials in children prenatally exposed to methylmercury. Neurotoxicology 37: 15-18. [Crossref]

34. Wannag A, Skjaeråsen J (1974) Mercury accumulation in placenta and foeta membranes. A study of dental workers and their babies. Environ Physiol Biochem 5: 348-352. [Crossref]

35. Lyttle HA, Bowden GH (1993) The level of mercury in human dental plaque and interaction in vitro between biofilms of Streptococcus mutans and dental amalgam. $J$ Dent Res 72: 1320-1324. [Crossref]

36. Michel I, Norbäck D, Edling C (1988) An epidemiologic study of the relation between symptoms of fatigue, dental amalgam and other factors. Swed Dent J 13: 33-38. [Crossref]

37. Bates MN, Fawcett J, Garrett N, Cutress T, Kjellstrom T (2004) Health effects of dental amalgam exposure: a retrospective cohort study. Int J Epidemiol 33: 894-902. [Crossref]

38. Messina MJ (2016) Dental amalgam: An inexpensive and safe option for filling cavities. Generations 40: 39-40.

39. Moraschini V, Fai CK, Alto RM, Dos Santos GO (2015) Amalgam and resin composite longevity of posterior restorations: A systematic review and meta-analysis. J Dent 43 1043-1050. [Crossref]

Copyright: (C2017 Andreescu CF. This is an open-access article distributed under the terms of the Creative Commons Attribution License, which permits unrestricted use, distribution, and reproduction in any medium, provided the original author and source are credited. 